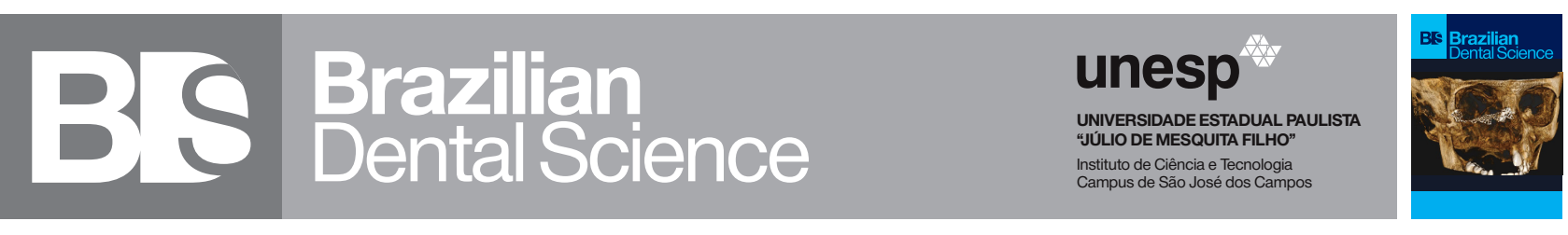

\title{
Severe hemorrhage in a patient with dengue hemorrhagic fever after insertion of orthodontic mini-implants. A case report
}

\author{
Hemorragia severa em paciente com dengue hemorrágica após instalação de miniimplante ortodôntico \\ Matheus Melo PITHON ${ }^{1,2}$ \\ 1 - Southwest Bahia University UESB - Bahia - Brazil. \\ 2 - School of Dentistry - Federal University of Rio de Janeiro - UFRJ - Brazil.
}

\begin{abstract}
The objective of this paper is to report a clinical case of a patient who after installing an orthodontic mini-implant returned to the dental office seven days later with a severe hemorrhage where it was inserted. Because of the severe character of the hemorrhage, the mini-implant was removed, local compression was performed, medication to control bleeding was given and some lab tests were requested. The patient returned in 24 hours with diagnosis of dengue hemorrhagic fever (DHF). The patient was referred to the specialized hematology service where the diagnosis was confirmed. Past the critical period, a new mini-implant was inserted to continue the orthodontic treatment. It can be concluded from this account that despite the miniimplants being devices of simple installation and easy removal, it is important that the patient's systemic conditions are optimal for their overall effectiveness.
\end{abstract}

\section{KEYWORDS}

Dengue; Hemorrhage; Orthodontic Anchorage Procedures.

\section{RESUMO}

O objetivo do presente artigo é relatar o caso clínico de paciente que após a instalação de um mini-implante ortodôntico retornou ao consultório sete dias depois com uma hemorragia severa no local da instalação do mesmo. Em virtude da característica severa da hemorragia o mini-implante foi removido, realizado compressão local, medicação para controle da hemorragia além de solicitação de alguns exames laboratoriais. O paciente retornou 24 horas com os resultados que evidenciaram que o mesmo apresentava-se quadro de dengue hemorrágica. $\mathrm{O}$ mesmo foi encaminhado ao serviço hematologico especializado onde o diagnóstico foi confirmado. Passado o período crítico novo miniimplante foi inserido para continuação do tratamento ortodôntico. Pode-se concluir com esse relato que apesar dos mini-impantes serem um recurso de simples instalação e fácil remoção é importante que as condições sistêmicas do paciente estejam boas para sua total efetividade

\section{PALAVRAS-CHAVE}

Dengue; Hemorragia; Procedimentos de Ancoragem Ortodôntica 


\section{INTRODUCTION}

$\mathrm{D}$ Dengue is a major public health problem worldwide, especially in tropical and subtropical regions $[1,2]$. Clinical symptoms start suddenly and widely, varying from oligosymptomatic (silent infection) and symptomatic (dengue fever) forms to severe states with hemorrhages (dengue hemorrhagic fever - DHF) and shock (dengue shock syndrome - DSS). [3,4].

Etiologically, the causative agent is a virus belonging to the Flaviviridae family with RNA genome and four known serotypes (DEN-1, DEN-2, DEN-3 and DEN-4).[3, 5, 6] Its transmission is made by the mosquito Aedes aegypti, the principal vector, which generally uses artificial containers for vector proliferation, making this species predominantly urban. [5-7]

According to estimations by the World Health Organization (WHO), 80 million people are infected annually, with approximately 550,000 hospitalizations and 20,000 deceases. $[8,9]$ Of these, approximately 50 million are found in tropical and subtropical regions, taking into consideration that currently, 2.5 to 3 billion people live at risk of being infected by this arbovirus. $[8,9]$

Because it is a very prevalent disease worldwide, orthodontic patients can be at risk. Thus, the proposal of the author with this article was to describe a rare clinical case of a patient who presented a severe hemorrhage where an orthodontic mini-implant was inserted after contracting DHF.

\section{CLINICAL CASE}

F.F.K., 30 years old patient came to the clinic with the main complaint of space between the teeth coming from an unsuccessful previous orthodontic treatment. In possession of anamnesis, clinical examination and laboratory tests (radiographs, photographs, cephalometric analysis and orthodontic models) orthodontic treatment began aiming at dental alignment and leveling associated with the closing of superior spaces with mesial movement of maxillary posterior teeth with mini orthodontic implants anchorage connected to sliding-jig. The patient had initially class I malocclusion with remaining spaces in the maxillary arch and the absence of element 24 (left first maxillary premolar) (Figure 1).

The orthodontic treatment started using a fixed orthodontic appliance following the edgewise standard slot 028"x.030" technique (Morelli, Sorocaba, Brazil) associated with levelling and alignment arcs .016", .018" and .020 ". About 6 months after the treatment initiation, orthodontic mini-implants were installed between (the upper left canine and second premolar) aiming at mesial movement of (the left first premolar). This treatment phase lasted for about 4 months when it was decided to remove the mini-implant from this position and install it afterwards in order to mesialize both upper left canine and second premolar. Thus, during this stage the mini-implant was removed and a new one was installed between (first and second left upper molar) (Figure 2). The installation of this device occurred with the utmost possible normality; initially anesthetizing superficially the gum, followed by its small perforation with cortical marking with an appropriate drill followed by the installation itself. 


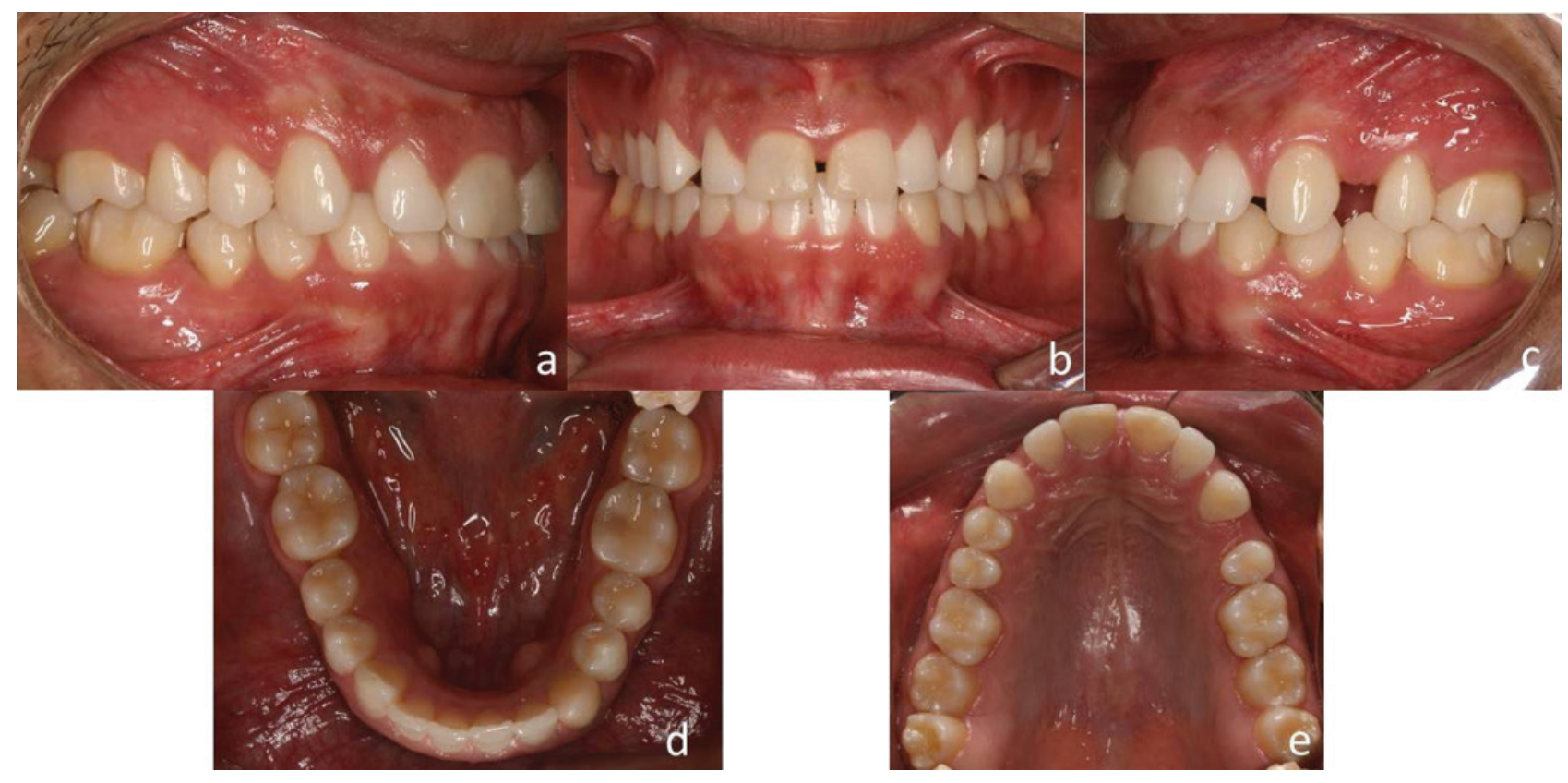

Figure 1 - a-e Intraoral photographs of the clinical case.

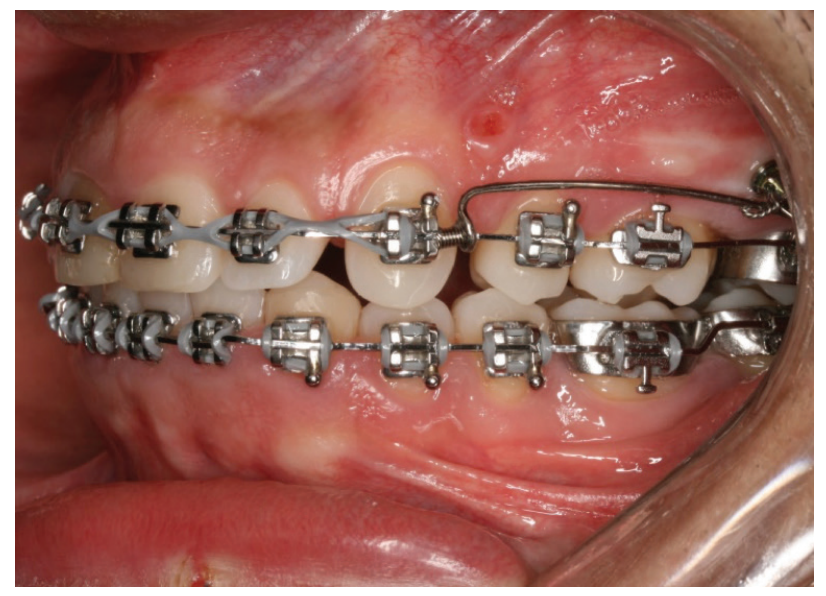

Figure 2 - Intraoral left side photography after orthodontic mini-implant placement.

The patient left the office without reporting pain or discomfort, this condition lasted for seven days according to the patient's account.

On the eighth day after installation of the mini-implant, the patient returned to the clinic complaining of spontaneous bleeding where the mini-implant was inserted, which, according to the patient, began after lunchtime when the patient was performing oral hygiene.
The patient came in around 2:00 pm, in that consultation the stability of the mini-implant was verified as well as the peri-implant health, and only mild hemorrhage. It was suspected that the wire ligature that kept the sliding-jig attached to the mini-implant could be piercing the gums causing the hemorrhage. Thus, the wire ligature was removed and a new one was placed in the same position, carefully as to avoid the ends being hurt.

2 hours after this consultation, the patient called the office reporting that the bleeding had restarted about 5 minutes earlier and apparently at a higher intensity. Immediate return of the patient to the office was solicited, where spontaneous bleeding with large peri-implant blood clot formation was verified (Figure 3 ).

According to the patient, on the way from his workplace to the dental office he filled two $50 \mathrm{ml}$ glasses of blood. At this stage, the removal of the mini-implant was decided together with the verification of what was happening. Jointly with the removal the all area was anesthetized with vasoconstrictor anesthetics (prilocaine hydrochloride with felypressin $0.03 \mathrm{IU} / \mathrm{ml}$, (Cristália, São Paulo, Brazil) in an attempt to 
stop the bleeding. Simultaneously, compression of the area where the mini-implant was removed was performed with a cotton roll for about 10 minutes (Figure 4). After this period it was found that the bleeding was reduced by about 50 $\%$. As final measure, $200 \mathrm{mg}$ of tranexamic acid (Transamin, Rio de Janeiro, Brazil) was applied. During the period in which the patient remained at the dental office, an inquiry regarding his general health was made. The patient reported headache and malaise in the body since about 3 days, which, he said, seemed to be only a form of influenza.

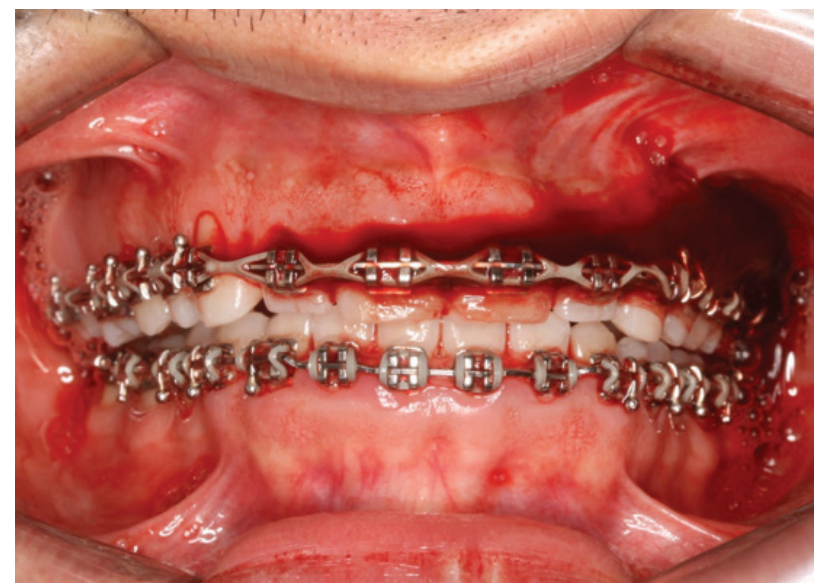

Figure $\mathbf{3}$ - Clinical aspect of the immense clot formed under the orthodontic appliance after 7 days of the mini-implant placement.

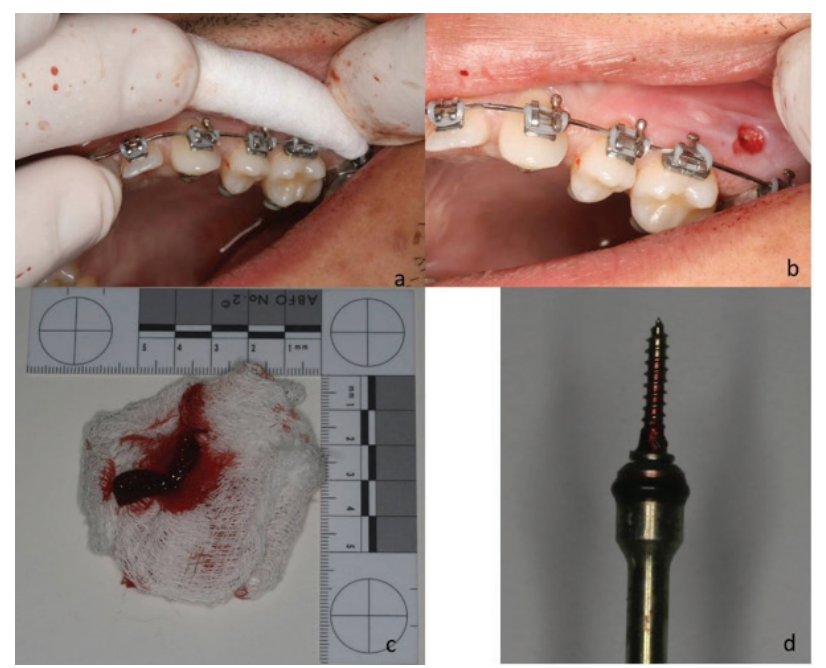

Figure 4 - Steps of the removal of the mini-implant: a) compression of the area where the mini-implant was removed; b) appearance after the bleeding stopped; c) clot removed from the area; and d). mini-implant removed.
With this information we requested immediately some laboratory tests. We also suggested the patient to seek a specialized hematology unit to check his health. 24 hours after having been to the clinic the patient returned and had no bleeding, but the clinical status of his overall health had worsened (Figure 5 a-b). The patient had brought his laboratory tests that showed alterations in coagulation factors and positive serology for dengue hemorrhagic fever. The patient was immediately taken to the hospital where the clinical status of dengue hemorrhagic fever was confirmed, necessitating his immediate hospitalization. In this phase, the patient had high fever, hemorrhagic phenomena, hepatomegaly and circulatory failure.

Through laboratory tests could be verified:

Hemogram: leukopenia, lymphocytosis with atypical lymphocytes, concentration and hematocrit thrombocytopenia (platelet count below 100.000/mm3). Hemoconcentration: increased hematocrit at $45 \%$ of baseline. Thrombocytopenia: platelet count below $100.000 / \mathrm{mm} 3$. Coagulation tests: increase in prothrombin time, partial thromboplastin time and thrombin. Reduction of fibrinogen, prothrombin, factor VI-II, factor XI- I, antithrombin and antiplasmin $\alpha$. Biochemistry: decreased albumin in the blood, albuminuria and discrete increase in liver function tests: serum aminotransferase and aspartate aminotransferase serum alanine.

Past 7 days after hospitalization, the patient was discharged. It was decided to meet the patient 27 days after occurrence of the facts. At this session it was decided to install new mini-implant for continuation of the treatment (Figure $5 \mathrm{c}-\mathrm{d}$ ). 


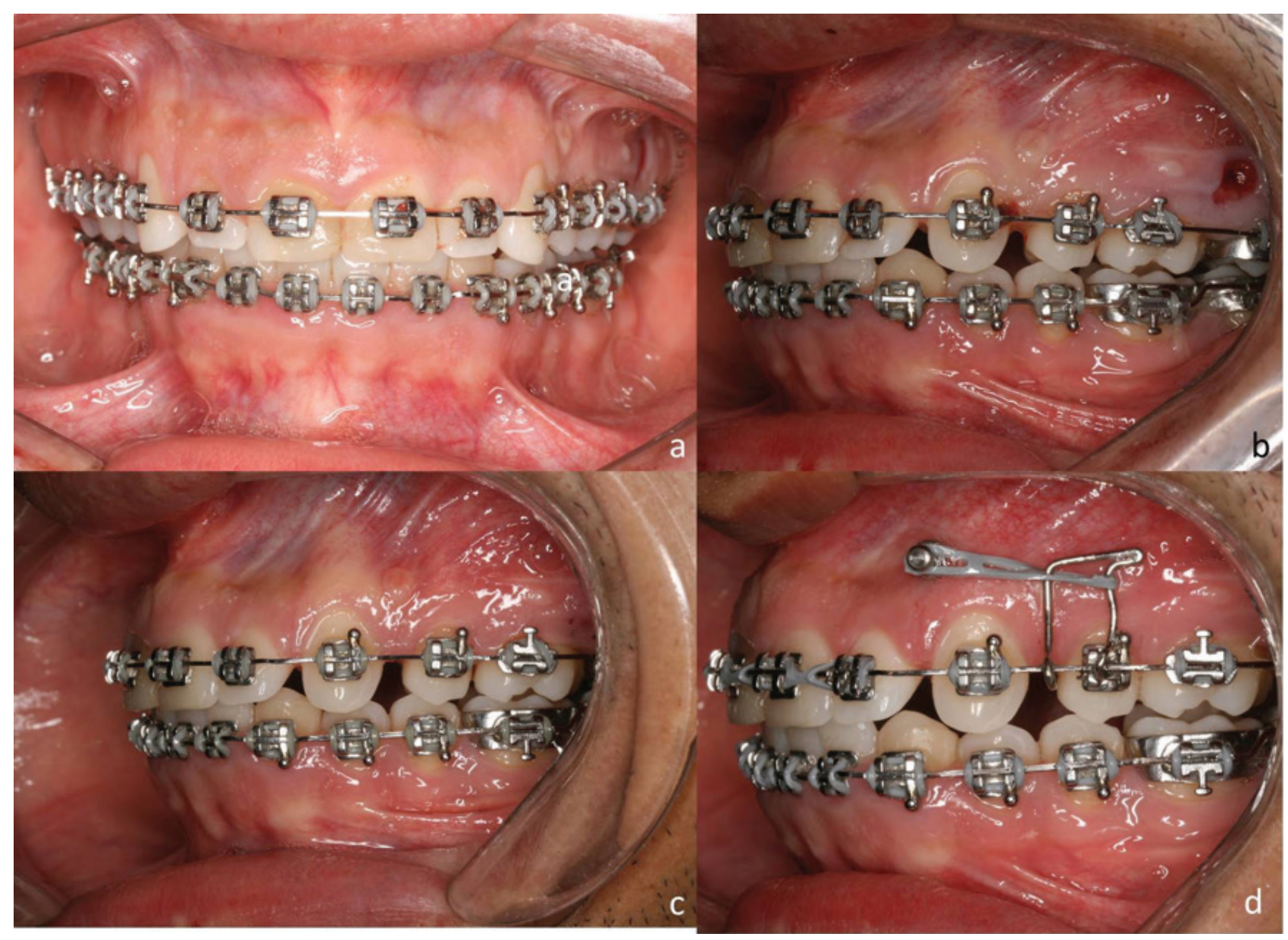

Figure 5 - a-b Frontal and left lateral intraoral photograph after the bleeding stopped; c- Appearance after 24 hours post removal of the mini-implant and d-Sequence of the treatment with installation of the new mini-implant previously localized.

\section{DISCUSSION}

The purpose of this case report was to describe a unique clinical situation, never reported before in the literature, which was severe hemorrhage, after installation of a miniimplant in a patient with clinical status of dengue hemorrhagic fever.

The diagnosis and management of gingival bleeding can be occasionally confusing and may require a systematic medical team approach. Oral manifestations of many hematological diseases are clinically similar to locally occurring lesions. $[10,11]$ For this reason, a specific diagnosis of blood dyscrasia is difficult, if not impossible, to establish on the basis of oral findings alone. The dentist may be the first health care professional to evaluate a patient with acute gingival bleeding owing to an underlying blood dyscrasia. Clinical history, systemic signs of a bleeding disorder, and abnormal tests for hemostasis may help the dentist in the early detection and referral of patients for further management. [10,12,13]

Causes of acute severe diffuse gingival bleeding include local and nondental causes, which include vitamin deficiencies, malignancies, such as leukemia, side effects of certain medications, and occasionally systemic diseases. Hemorrhagic disorders in which abnormal gingival bleeding is encountered include vascular abnormalities (vitamin C deficiency or allergy, e.g., Henoch-Schönlein purpura), platelet disorders [14] (e.g., thrombocytopenic purpura), hypoprothrombinemia (vitamin $\mathrm{K}$ 
deficiency), other coagulation defects (e.g., hemophilia), deficient platelet thromboplastic factor (PF3) resulting from uremia, [15] multiple myeloma, [16] leukemia, [17] and postrubella purpura. [18] Certain autoimmune disorders, such as rheumatoid arthritis, systemic lupus erythematosus, and Hashimoto thyroiditis can result in gingival bleeding. [19,20] Gingival bleeding can also occur as a side effect of certain medications, such as aspirin, anticoagulants, oral contraceptives, [21] antihypertensive calcium channel blockers, anticonvulsants, and certain immunosuppressant drugs. [22] A viral disease such as dengue hemorrhagic fever can also be related to bleeding episodes.

The main vector for the dengue virus is Aedes aegypti, a mosquito, found worldwide between latitudes $35^{\circ} \mathrm{N}$ and $35^{\circ} \mathrm{S}$. [23] Dengue has been reported in almost 70 countries, including the Caribbean, South and Central America, Mexico, Africa, the Pacific Islands, Southeast Asia, the Indian subcontinent, Hawaii, and Australia, with about 5 million cases reported between 2000 and 2007.[23, 24] In 2010, 1.6 million cases of dengue were reported in the Americas alone, of which 49,000 cases were severe dengue.[5, 9] According to the European Network on Imported Infectious Disease Surveillance (TropNetEurop), the number of reported dengue cases in Europe increased from 64 in 1999 to 224 in 2002 and has remained at 100 to 170 since then. [5,9] Mortality from dengue varies greatly across countries, but the World Health Organization (WHO) estimates that about 22,000 deaths are associated with dengue every year. [24]

Because it is a prevalent medical condition worldwide, its interrelation with any other clinical situation is of interest. Orthodontics is no exception to the rule, considering that for an effective orthodontic treatment without complications the patient's general health must be good.

Because thrombocytopenia occurs, it is logical that the treatment should follow guidelines as established for other thrombocytopenic conditions (e.g., idiopathic thrombocytopenic purpura). Efforts should be made to correct the platelet deficiency with infusion of platelets or fresh blood under strict medical supervision, in addition to fluid management to prevent shock. Local measures to control hemorrhage should also be used judiciously. Pressure pack with or without the support of a splint is probably the most important technique to control socket bleeding. Local hemostatic agents, such as gelfoam, oxidized cellulose, botropase, and adrenaline, are also commonly used for this purpose. Antifibrinolytic agents, such as aminocaproic acid and tranexemic acid, are useful in preventing clot lysis following oral surgery or dental extraction in patients with coagulation defects. They are used as adjuncts to specific systemic therapy that corrects the coagulation factor or platelet abnormality Any large, exophytic clots should be removed down to the level of the socket, as they may provide a pathway for continued bleeding and prevent application of adequate pressure to the site. [25]

In this case, all these clinical procedures described in the literature were performed. Initially the area was numbed up with anesthetics with adrenaline that allowed bleeding reduction by local vasoconstriction. Following the removal of the mini-implant, the area was compressed with cotton and as final measure $200 \mathrm{mg}$ of tranexamic acid was applied. After the adoption of all these measures the bleeding ceased.

It is important to note that successful orthodontic practice does not only involve the field of corrective technique to achieve perfect dental occlusion, but also requires care regarding local and systemic consequences that orthodontic appliances may cause.

\section{CONCLUSION}

It is concluded with this case description that despite mini-implants installation being considered easy and fast, patients' systemic conditions must be in good in order to obtain predictable orthodontic results without harming the patient. 


\section{REFERENCES}

1. AntinoriS, Morena V,Pagani G, Venturi G, Giacomelli A, Milazzo L, Ridolfo AL, Zanchetta N. Dengue fever complicated by liver dysfunction due to possible co-infection with hepatitis E in a returning traveller from Cuba. Infez Med. 2020 Mar 1,28(1):98-103.PMID:32172268.

2. Faridah L, Rinawan FR, Fauziah N, Mayasari W, Dwiartama A, Watanabe K. Evaluation of Health Information System (HIS) in The Surveillance of Dengue in Indonesia: Lessons from Case in Bandung, West Java. Int J Environ Res Public Health. 2020 Mar 10;17(5):1795. doi:10.3390/ijerph17051795. PMID:32164243; PMCID:PMC7084631.

3. Costa AG, Santos JD, Conceição JK, Alecrim PH, Casseb AA, Batista WC, Heckmann MI. Dengue: aspectos epidemiológicos e o primeiro surto ocorrido na região do Médio Solimões, Coari, Estado do Amazonas, no período de 2008 a 2009 [Dengue: epidemiological aspects and the first outbreak in the Middle Solimões Region of Coari in the State of Amazonas from 2008 to 2009]. Rev Soc Bras Med Trop. 2011 Jul-Aug;44(4):471-4. Portuguese. doi: 10.1590/s003786822011000400014.PMID:21860893.

4. Tiga-Loza DC, Martínez-Vega RA, Undurraga EA, TschampI CA, ShepardDS, Ramos-Castañeda J. Persistence of symptoms in dengue patients: a clinical cohort study. Trans RSoc Trop Med Hyg.2020 May 7;114(5):355-364. doi: 10.1093/trstmh/traa007.PMID:32125417.

5. Donnio A, Béral L, Olindo S, Cabie A, Merle H. La dengue, une nouvelle étiologie de paralysie oculomotrice [Dengue, a new etiology in oculomotor paralysis]. Can J Ophthalmol. 2010 Apr;45(2):183-4. French. doi: 10.1139/i09-207.PMID: 20379314.

6. Campagna DdeS, Miagostovich MP,Siqueira MM, Cunha RV. Etiology of exanthema in children in a dengue endemic area.JPediatr (Rio J). 2006 SepOct;82(5):354-8. doi: 10.2223/JPED.1522. Epub 2006 Aug 28. PMID: 16951800.

7. CruzLCTAD, Guimarães AGF, Souza EM, Ferreira RDS, Gomes RSR, Slhessarenko RD, Atanaka M. Influence of climatic variables on the Aedes aegypti and Culex quinquefasciatus populations in Mato Grosso, Brazil. Rev Soc Bras Med Trop. 2020 Mar 16;53:e20190185. doi: 10.1590/0037-8682-01852019.PMID:32187334; PMCID:PMC7094053.

8. Joob B, Wiwanitkit V. Death due to dengue fever. Scand J Infect Dis. 2014 Jun;46(6):478. doi: 10.3109/00365548.2014.898335. Epub 2014 Apr 10. PMID: 24717167.

9. Branco Mdos R, LunaEJ, Braga Júnior LL, Oliveira RV, Rios LT, Silva Mdo S, Medeiros MN, Silva GF, Nina FC, Lima TJ, Brito JA, Oliveira AC, PannutiCS. Risk factors associated with death in Brazilian children with severe dengue: a case-control study. Clinics (Sao Paulo).2014 Jan;69(1):55-60. doi:10.6061/ clinics/2014(01)08.PMID:24473560; PMCID:PMC3870309.

10. Khan S, Gupta ND, Maheshwari S. Acute gingival bleeding as a complication of dengue hemorrhagic fever. J Indian Soc Periodontol. 2013 Jul;17(4):520-2 doi: 10.4103/0972-124X.118328.PMID:24174736;PMCID:PMC3800419.

11. Planerova A, Philip S, Elad S. Gingival bleeding in a patient with autism spectrum disorder: A key finding leading to a diagnosis of scurvy. Quintessence Int 2017;48(5):407-411. doi: 10.3290/j.q.a38060.PMID: 28396889
12. Joob B, Wiwanitkit V.Dengue and acute gingival bleeding. J Indian Soc Periodontol. 2014 Jan;18(1):4. doi:10.4103/0972-124X.128189.PMID:24744535; PMCID:PMC3988641.

13. Khan S, Zia A, Gupta ND, Bey A. Acute gingival bleeding as a complication of falciparum malaria: a case report. Oral Surg Oral Med Oral Pathol Oral Radiol. 2012 May;113(5):e19-22. doi: 10.1016/j.0000.2011.10.016. Epub 2012 Mar 3.PMID: 22668636.

14. Staub HP.Postrubella thrombocytopenic purpura. A report of eight cases with discussion of hemorrhagic manifestations of rubella. Clin Pediatr (Phila). 1968 Jun;7(6):350-6. doi: 10.1177/000992286800700611.PMID:5300740.

15. Grellet M. Emorragie gengivali e dell'alveolo dentario [Gingival or dental alveolar hemorrhages]. Recenti Prog Med. 1969 Jan;46(1):62-6. Italian. PMID:5306181.

16. Bennett JH, Shankar S. Gingival bleeding as the presenting feature of multiple myeloma. Br Dent J. 1984 Aug 11;157(3):101-2. doi: 10.1038/sj.bdj.4805423. PMID: 6332637.

17. Deasy MJ, Vogel RI, Annes IK, Simon BI. Periodontal disease associated with preleukemic syndrome.J Periodontol. 1976 Jan;47(1):41-5. doi: 10.1902/ jop.1976.471.41.PMID: 1063853.

18. Hoover DR, Lefkowitz W. Fluctuation in marginal gingivitis. J Periodontol. 1965 Jul-Aug;36:310-4. doi: 10.1902/jop.1965.36.4.310.PMID: 14326698.

19. Taub JW, Warrier I, Holtkamp C, Beardsley DS, Lusher JM. Characterization of autoantibodies against the platelet glycoprotein antigens Ilb/Illa in childhood idiopathic thrombocytopenia purpura. Am J Hematol. 1995 Feb;48(2):104-7. doi: 10.1002/ajh.2830480207.PMID: 7847322.

20. Krivy J,Wiener J. Sertraline and platelet counts in idiopathic thrombocytopenia purpura. Lancet. 1995 Jan 14;345(8942):132. doi: 10.1016/s0140-6736(95)901019.PMID: 7815874.

21. Machtei EE, Mahler D, Sanduri H, Peled M. The effect of menstrual cycle on periodontal health.J Periodontol. 2004 Mar;75(3):408-12. doi: 10.1902/ jop.2004.75.3.408.PMID: 15088879

22. Gordon SC, Daley TD. Foreign body gingivitis: clinical and microscopic features of 61 cases. Oral Surg Oral Med Oral Pathol Oral Radiol Endod. 1997 May;83(5):562-70. doi:10.1016/s1079-2104(97)90121-9.PMID: 9159816.

23. Dubey P,Kumar S, Bansal V, Kumar KV, Mowar A, Khare G. Postextraction bleeding following a fever: a case report. Oral Surg Oral Med Oral Pathol Oral Radiol. 2013 Jan;115(1):e27-31. doi: 10.1016/j.0000.2012.03.038. Epub 2012 Sep 21. PMID:22999964

24. LeDuc JW. Epidemiology of hemorrhagic fever viruses. Rev Infect Dis. 1989 May-Jun;11Suppl 4:S730-5. doi:10.1093/clinids/11.supplement_4.s730.PMID: 2546247.

25. Teixeira MG, Barreto ML. Diagnosis and management of dengue. BMJ. 2009 Nov 18;339:b4338. doi:10.1136/bmj.b4338. Erratum in:BMJ.2009. doi:10.1136/ bmj.b5522.PMID: 19923152.

\section{Matheus Melo Pithon} (Corresponding address)

Av. Otávio Santos, 395, sala 705, Centro Odontomédico Dr. Altamirando da Costa Lima. Vitória da Conquista, Bahia, Brazil. CEP: 45020-750

E-mail: matheuspithon@gmail.com

Date submitted: 2020 Jan 08 Accept submission: 2020 Apr 02 